\title{
Bimbingan Kelompok dengan Teknik Self-Instruction untuk Meningkatkan Self-Regulation Siswa
}

\author{
Bambang Setiawan ${ }^{* 1}$, Muhammad Solehuddin ${ }^{2}$, Anne Hafina ${ }^{3}$ \\ ${ }^{1}$ IAIN Syekh Nurjati Cirebon 1, Indonesia, ${ }^{2}$ Universtitas Pendidikan Indonesia 2, Indonesia, \\ ${ }^{3}$ Universtitas Pendidikan Indonesia 3, Indonesia \\ *)Corresponding author, E-mail: setiawan89.bambang@gmail.com
}

\begin{abstract}
Abstrak. Penelitian ini dilakukan untuk menguji efektivitas bimbingan kelompok dengan teknik self-instruction untuk meningkatkan self-regulation siswa. Self-regulation diibaratkan sebagai kartu as dari kepribadian individu, yang diasumsikan dapat memperkuat diri individu dan meningkatkan kemampuan dalam menghadapi tuntutan kehidupan serta sebagai pembimbing perilaku individu. Selain itu, rendahnya selfregulation akan menyebabkan cakupan permasalahan yang luas, khususnya pada siswa yang akan mengganggu terhadap pencapaian prestasi akademik siswa. Pada penelitian ini digunakan pendekatan kuantitatif, dengan desain penelitian eksperimen kuasi, dan metode penelitian non-equivalent pretest-posttest control group design. Pengambilan sampel dalam penelitian ini menggunakan teknik purposive sampling, dengan jumlah sampel penelitian 69 orang siswa, yang terbagi ke dalam kelas eksperimen sejumlah 39 orang, dan kelas kontrol sejumlah 30 orang. Hasil penelitian menunjukan bahwa secara umum profil self-regulation siswa berada pada kategori sedang, dan secara empiris pemberian layanan bimbingan kelompok dengan teknik self-instruction terbukti efektif untuk meningkatkan self-regulation siswa.
\end{abstract}

Kata Kunci: Self-Regulation; Bimbingan Kelompok; Teknik Self-Instruction.

\begin{abstract}
Triggered by the importance of self-regulation, then this research was conducted in order to test the effectiveness of group guidance with self-instruction technique in order to enhance self-regulation of the students. Self-regulation is considered as the As card of human personality as it is assumed to be able to strengthen and increase the ability of a person to face the demand of living as well as act as a guide of behaviors of the person himself. In addition, lack of self-regulation will also cause a wide range of problems specifically for the students as it may affect the academic achievement of the students themselves. A quantitative approach with the quasyexperimental design was used in this research. Meanwhile, the research method used was the non-equivalent pretest-posttest control group design. The selection of the sample of the study was by using the purposive sampling technique, the total samples taken were 69 students, 39 students were placed in the experimental group and other 30 students were in the control group. The study found that in general the profile of the students' self-regulation was on the moderate category, and empirically the group guidance with self-instruction technique was proven to be able to enhance students' selfregulation.
\end{abstract}

Keywords: Self-Regulation; Group Guidance; Self-Instruction Technique.

This is an open access article distributed under the Creative Commons Attribution License, which permits unrestricted use, distribution, and reproduction in any medium, provided the original work is properly cited. (C2019 by author.

\section{Pendahuluan}

Manusia sebagai makhluk sosial dipengaruhi oleh faktor eksternal, akan tetapi manusia juga memiliki kemampuan untuk mengendalikan dirinya terhadap pengaruh faktor eksternal. Seperti dijelaskan Bandura (1991) apabila perilaku manusia hanya diatur oleh faktor eksternal maka manusia akan berperilaku seperti baling-baling, secara konstan berganti arah menyesuaikan diri terhadap pengaruh sosial 


\section{KONSELING: Jurnal Ilmiah Bimbingan dan Konseling}

Vol.1, No.1, Oktober 2019

Available online: https://journal.ilininstitute.com/konseling

Bambang Setiawan, M. Solehuddin, Anne Hafina

yang dialaminya. Bandura memandang bahwa manusia dapat berpikir dan melakukan regulasi terhadap perilakunya sendiri, serta bukanlah pion dari pengaruh lingkungan (Hall \& Lindzey, 1985, hlm. 536).

Kualitas paling penting sebagai manusia adalah kemampuan untuk meregulasi diri (Zimmerman, 2000). Kemampuan meregulasi diri merupakan sifat yang dimiliki oleh manusia yang membedakan manusia dengan makhluk hidup lainnya, dengan memiliki self-regulation manusia dapat mengendalikan pikiran, perasaan, dorongan, dan tindakannya, serta dapat membuat tujuan-tujuan yang adaptif. Para tokoh memiliki pandangan masing-masing dalam mendefinisikan self-regulation, Carver dan Scheier (2000) menekankan pada proses pengawasan yang melibatkan kesadaran diri dan proses timbal balik berdasarkan perbandingan pencapaian diri dengan standar yang ada; Trope dan Liberman (2000) menekankan pada aspek kognitif; Mischel (1996) menekankan pada strategi kognitif individu dalam menentang godaan sementara, guna mencapai tujuan jangka panjang yang adaptif; dan Higgins (1996) berfokus pada perbedaan jenis standar dengan faktor diri (self) dan emosi.

Self-regulation berperan penting dalam membantu siswa mencapai prestasi akademis dan mengendalikan perilaku siswa. Siswa yang memiliki self-regulation secara aktif dan konstruktif dapat menyesuaikan pikiran, perasaan, dan tindakan sebagai sebuah kebutuhan untuk mempengaruhi dan memotivasi belajarnya (Boekaerts \& Corno, 2005). Selain itu, diungkapkan pula oleh Blair et al. (2010) bahwa pengaruh positif self-regulation dapat meningkatkan kontrol siswa untuk merasakan dan meyakini mengenai usaha-usaha yang berdampak terhadap pencapaian prestasi akademiknya.

Husna et al. (2014) mengungkapkan bahwa siswa yang memiliki self-regulation cenderung berhasil secara akademik, mampu belajar secara efektif dengan mengkombinasikan keterampilan belajar akademis dan kontrol diri yang membuat proses belajar menjadi lebih mudah sehingga siswa lebih termotivasi. Ditambahkan pula oleh Chong (2007) bahwa pengembangan kemampuan self-regulation merupakan faktor yang penting bagi siswa karena regulasi perilaku berguna untuk mencapai pembelajaran yang efektif. Sementara itu, Bukhtawer et al. (2014) menemukan hasil bahwa personality traits berkorelasi dengan selfregulation dalam mengendalikan perilaku impulsif dan adiksi para pecandu narkoba. Berdasarkan temuan ini, self-regulation berperan dalam mengendalikan tingkat impulsif dan adiksi yang disesuaikan dengan personality traits pecandu narkoba, yakni extraversion-introversion, neuroticism, dan psychoticism.

Boekaerts \& Corno (2005) menambahkan bahwa kapasitas self-regulation merupakan pusat terhadap asumsi mengenai belajar, pembuatan keputusan, pemecahan masalah, dan sumber daya dalam mengelola pendidikan. Berdasarkan pandangan teori sosial-kognitif, self-regulation merupakan hasil proses interaksi triadic atau tritunggal antara manusia (personal), perilaku (behavioral), dan lingkungan (environmental). Artinya self-regulation tidak hanya mengatur perilaku terhadap kemungkinan dari pengaruh lingkungan, tetapi juga pengetahuan dan perasaan untuk menjadikan perilaku tersebut sesuai dengan konteks, standar, dan aturan yang berlaku di masyarakat.

Self-regulation yang rendah berkaitan dengan cakupan permasalahan pribadi yang cukup luas, Ross \& Fontao (2007) menemukan bahwa terdapat hubungan antara rendahnya self-regulation dengan perilaku agresi. Hasil penelitian lainnya membuktikan bahwa siswa yang memiliki self-regulation rendah mengalami kesulitan dalam mengatur emosi dan perilakunya, sebagai konsekuensinya akan berdampak pada kesulitan dalam belajar serta terbuangnya beberapa keterampilan sosial dan kognitif yang diperlukan dalam mencapai prestasi akademik (Eisenberg et al. 2005; Blair et al., 2010). Rendahnya self-regulation berkontribusi terhadap berbagai dimensi permasalahan underachievement, seperti siswa kurang mampu menghadapi kegagalan dalam belajar; kurang mampu membuat pilihan yang efektif dalam meningkatkan prestasi belajar; kurang mampu menetapkan dan mencapai tujuan; dan kurang mampu mempertahankan performa belajar optimal dalam kurun waktu lama (Baumeister et al., 2006).

Zimmerman \& Schunk (2008) memandang bahwa perbedaan tinggi atau rendahnya pencapaian akademik siswa erat kaitannya dengan tingkat self-regulation yang dimiliki siswa. Self-regulation merupakan faktor yang esensial dalam proses belajar siswa, hal ini dikarenakan 1) self-regulation dapat membantu siswa menciptakan kebiasaan belajar dan keterampilan belajar yang lebih baik; 2) melatih siswa mampu menerapkan strategi belajar untuk meningkatkan prestasi akademik; 3) mengawasi performa akademik; dan 4) mengevaluasi perkembangan akademik (de Bruin et al., 2001; Harris et al., 2005; Zimmerman, 2008; Jarvela \& Jarvenoja, 2011; Wolters, 2011).

Dalam penelitian ini self-regulation berkaitan dengan perubahan kognitif untuk menanamkan standar internal dalam diri siswa, sehingga dapat mengontrol perilaku yang sesuai dengan standar internalnya. Dijelaskan oleh Meichenbaum (Dobson \& Dozois, 2001) bahwa perubahan kognitif pada individu bisa diubah dengan menggunakan verbalisasi diri. Ditambahkan pula oleh Skinner (Hughes, 1985) bahwa verbalisasi diri dapat digunakan oleh individu sebagai cara untuk mengontrol diri.

Teknik self-instruction merupakan salah satu teknik dari teori cognitive-behavior modification yang menggunakan pola verbalisasi diri. Teknik self-instruction membantu siswa untuk mengelola dirinya dengan memberikan instruksi-instruksi positif dan berupaya menghindari instruksi negatif. Tujuan dari self- 
instruction seperti yang diungkapkan oleh Meichenbaum \& Goodman (Hughes, 1985) adalah untuk meningkatkan individu dengan mengembangkan "learning set" yang digunakan untuk memunculkan kontrol dirinya.

Teknik self-instruction merupakan teknik yang tepat untuk menangani masalah emosional dan masalah perilaku, karena self-instruction dirancang untuk memberikan individu strategi pemecahan masalah yang dapat diaplikasikan terhadap perilakunya sendiri (Bryant \& Budd, 1982; Hughes, 1985). Burgio et al. (1980) berhasil melakukan penelitian dengan menggunakan self-instruction dalam mengembangkan kontrol diri dengan area perilaku yang luas, variabel perilaku yang ditelitinya antara lain, resistance to temptation, attentional problems, aggression, academic performance, serta berbagai perilaku pribadi dan sosial. Sementara itu, Bugenthal et al. (1978) menemukan hasil bahwa self-instruction memberikan keuntungan jangka panjang dalam peningkatan persepsi anak terhadap kemampuannya untuk mengontrol performa akademiknya sendiri.

Pemaparan mengenai teknik self-instruction dari beberapa ahli memberikan pengerucutan definisi teknik self-instruction dalam penelitian ini. Teknik self-instruction diartikan sebagai teknik verbalisasi diri yang digunakan untuk merubah verbalisasi diri siswa yang negatif digantikan oleh verbalisasi diri yang positif yang dapat meningkatkan self-regulation siswa. Penggunaan teknik self-instruction dalam meningkatkan self-regulation siswa bertujuan untuk restrukturisasi kognitif siswa melalui perubahan pola verbalisasi diri (self-statement) yang positif sehingga akan menghasilkan perilaku yang adaptif.

Intervensi teknik self-instruction dalam penelitian ini diberikan dengan menggunakan seting bimbingan kelompok, berdasarkan pada asumsi yang dikemukakan oleh Surya \& Natawidjaja (Rusmana, 2009) bahwa: 1) bimbingan kelompok lebih bersifat efektif dan efisien; 2) bimbingan kelompok dapat memanfaatkan pengaruh individu atau beberapa orang individu terhadap anggota lainnya; dan 3) dalam bimbingan kelompok terjadi saling tukar pengalaman diantara anggota kelompok yang dapat berpengaruh terhadap perubahan tingkah laku individu. Strategi pembelajaran yang diberikan dalam seting kelompok dipercaya dapat membantu peningkatan self-regulation dan pemahaman siswa terhadap konten pembelajaran. Berdasarkan latar belakang dan kerangka berpikir diatas, penelitian ini bertujuan untuk menguji efektivitas bimbingan kelompok dengan teknik self-instruction untuk meningkatkan self-regulation siswa kelas X SMK Negeri 1 Talaga.

\section{Metode}

Penelitian ini dimaksudkan menguji bimbingan kelompok dengan teknik self-instruction yang efektif untuk meningkatkan self-regulation siswa. Oleh sebab itu, pendekatan penelitian yang digunakan dalam penelitian ini adalah pendekatan kuantitatif, dengan desain penelitian eksperimen kuasi. Eksperimen kuasi merupakan desain penelitian yang memiliki kelompok kontrol, tetapi tidak dapat berfungsi sepenuhnya untuk mengendalikan variabel luar yang mempengaruhi pelaksanaan eksperimen.

Metode penelitian yang digunakan adalah nonequivalent pretest-posttest control group design, yaitu desain penelitian yang dilaksanakan terhadap dua kelompok, yakni kelompok eksperimen dan kelompok kontrol. Kelompok eksperimen diberikan intervensi layanan bimbingan kelompok dengan teknik selfinstruction, sementara kelompok kontrol selaku kelompok pembanding tidak diberikan intervensi. Kedua kelompok menjalankan pre-test dan post-test dengan tujuan menguji dampak variabel independen $\mathrm{X}$ yang terefleksikan dalam perbedaan pada variabel dependen, khususnya antara $\mathrm{O}_{2}$ dan $\mathrm{O}_{4}$.

Dalam penelitian ini, pemilihan kelompok eksperimen dan kelompok kontrol tidak menggunakan penugasan acak (random assignment) melainkan menggunakan kelompok yang sudah terbentuk (intact group), yaitu kelas biasa (Furqon \& Emilia, 2010, hlm. 20). Hal ini sesuai dengan Campbell \& Stanley (1963) yang mengemukakan bahwa eksperimen kuasi sebagai eksperimen yang memiliki perlakuan pengukuran dampak terhadap unit eksperimen, namun tidak menggunakan penugasan acak (random assignment) dalam rangka menyimpulkan perubahan yang disebabkan oleh perlakuan.

Data pre-test dan post-test diambil melalui instumen pengungkap tingkat self-regulation siswa, yang dikembangkan dari definisi operasional variabel self-regulation. Instrumen yang digunakan berupa inventori tertutup, yang mana responden tinggal memberikan jawaban yang sesuai dengan dirinya pada pilihan jawaban yang ada. Inventori ini menggunakan model skala Likert yang terdiri dari pernyataan positif dan pernyataan negatif dengan lima alternatif jawaban, yaitu Sangat Sesuai (SS); Sesuai (S); Ragu-Ragu (R); Tidak Sesuai (TS); dan Sangat Tidak Sesuai (STS), dengan skor berkisar antara 0 sampai 4.

Pengambilan sampel penelitian menggunakan teknik purposive sampling. Pemilihan teknik purposive sampling dilakukan atas dasar pertimbangan tingkat self-regulation populasi penelitian yang berada pada tingkatan terendah yang diungkap melalui instrumen self-regulation. Jadi dalam penelitian eksperimen kuasi ini pengambilan sampel menggunakan seluruh subjek dalam kelompok belajar (intact group) untuk diberi perlakuan (treatment), bukan menggunakan subjek yang diambil secara acak. Pengambilan sampel secara purposive bertujuan agar sampel yang diambil dapat mewakili populasi, sehingga diperoleh informasi yang cukup untuk mengestimasi populasinya. 


\section{KONSELING: Jurnal Ilmiah Bimbingan dan Konseling}

Vol.1, No.1, Oktober 2019

Available online: https://journal.ilininstitute.com/konseling

Bambang Setiawan, M. Solehuddin, Anne Hafina

Sampel dalam penelitian ini adalah siswa kelas X SMK Negeri 1 Talaga yang secara umum memiliki tingkat self-regulation paling rendah. Dua kelas yang mendapatkan rata-rata skor tingkat selfregulation paling rendah yaitu kelas X TSM1 sebagai kelas eksperimen, dan kelas X BR sebagai kelas kontrol. Untuk lebih jelas, sampel penelitian dalam penelitian ini disajikan dalam Tabel 1 berikut.

Tabel 1. Sampel Penelitian

\begin{tabular}{llccccccc}
\hline No & Kelas & \multicolumn{3}{c}{ Frekuensi } & \multicolumn{3}{c}{ Persentase } & Tingkat Self- \\
\cline { 3 - 7 } & & T & S & R & T & S & R & Regulation \\
\hline $\mathbf{1}$ & X TSM1 & 9 & 30 & 0 & 23,08 & 76,92 & 0 & 62,07 \\
$\mathbf{2}$ & X BR & 6 & 24 & 0 & 20 & 80 & 0 & 62,31 \\
\hline
\end{tabular}

\section{Hasil dan Pembahasan}

Berdasarkan hasil penelitian, profil umum self-regulation siswa memperoleh rata-rata skor tingkat selfregulation sebesar 65,80 . Hal ini menunjukkan bahwa profil self-regulation siswa berada pada kategori sedang, artinya adalah siswa belum sepenuhnya memahami peran dan tanggung jawab sebagai siswa, anak, dan anggota masyarakat; kurang mampu memotivasi diri dalam proses pencapaian prestasi belajar; kurang mampu menghindari tindakan-tindakan yang dapat mengganggu pencapaian prestasi belajar; mengetahui kelebihan dan kekurangan tetapi belum dapat mengembangkan diri secara optimal; dan belum sepenuhnya bertindak secara positif sesuai peran dan tanggung jawab guna meraih tujuan belajar optimal. Distribusi frekuensi profil self-regulation siswa dari jumlah populasi 440 orang siswa disajikan dalam Tabel 2 berikut.

Tabel 2. Distribusi Frekuensi Profil Umum Self-Regulation Siswa

\begin{tabular}{ccccc}
\hline No. & Kategori & f & Persentasi (\%) & Tingkat Self-Regulation \\
\hline $\mathbf{1}$ & Tinggi & 197 & 44,77 & 65,80 \\
$\mathbf{2}$ & Sedang & 243 & 55,23 & \\
$\mathbf{3}$ & Rendah & 0 & 0 & \\
& Jumlah & 440 & 100 & \\
\hline
\end{tabular}

Apabila dilihat berdasarkan aspek-aspek self-regulation, profil umum self-regulation pada aspek 1 forethought memperoleh rata-rata skor sebesar 68,97 atau berada pada kategori tinggi, hal ini menggambarkan bahwa siswa memahami peran dan tanggung jawabnya sebagai siswa, anak, dan anggota masyarakat, dan mampu memotivasi dirinya dalam proses pencapaian prestasi belajar. Pada aspek 2 performance/volitional control memperoleh rata-rata skor sebesar 61,00 atau berada pada kategori sedang, hal ini menggambarkan bahwa siswa kurang mampu menghindari tindakan-tindakan yang dapat mengganggu pencapaian prestasi belajarnya. Pada aspek 3 self-reflection memperoleh rata-rata skor sebesar 67,53 atau berada pada kategori tinggi, hal ini menggambarkan bahwa siswa mengetahui kelebihan dan kekurangannya dalam mencapai pengembangan diri optimal, dan siswa senantiasa bertindak positif sesuai peran dan tanggung jawabnya dalam mencapai tujuan belajar optimal. Untuk lebih jelas tingkat selfregulation siswa berdasarkan aspek dapat dilihat pada Grafik 1 berikut.

Grafik 1. Tingkat Self-Regulation Siswa Berdasarkan Aspek

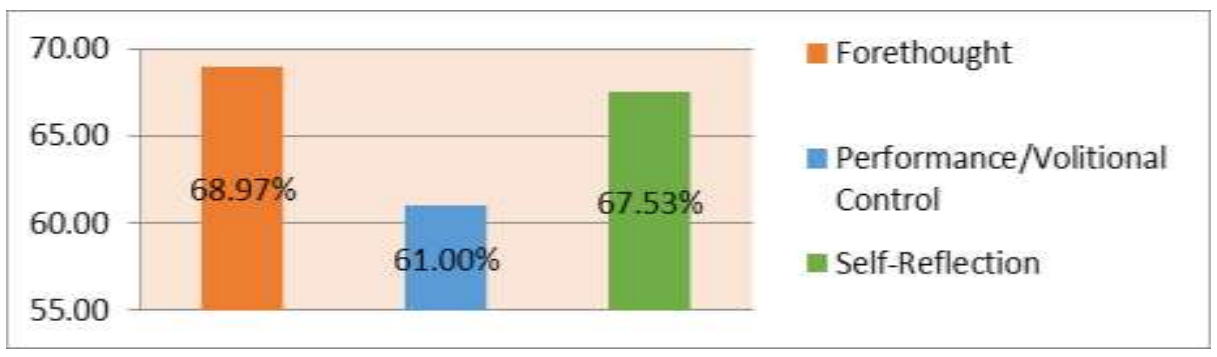

Untuk mengetahui keefektifan bimbingan kelompok dengan teknik self-instruction untuk meningkatkan self-regulation siswa dilihat berdasarkan uji kesamaan dua rata-rata atau uji-t Independent Sample T-Test. Uji independent sample t-tes dilakukan untuk menguji signifikansi pada setiap aspek selfregulation siswa. Sebelum menguji signifikansi self-regulation siswa pada setiap aspek pada post-test, akan lebih baik terlebih dahulu mengetahui tingkat signifikansi self-regulation siswa pada setiap aspek sebelum pemberian layanan sebagai berikut. 
Tabel 3. Uji Independent Sample t-test Kelas Eksperimen dan Kelas Kontrol (Pre-Test)

\begin{tabular}{ccccc}
\hline No. & Aspek & Asymp. Sig (2-tailed) & $\boldsymbol{\alpha}$ & Keterangan \\
\hline 1. & Forethought & 0.990 & 0.05 & Tidak Signifikan \\
2. & Performance/Volitional Control & 0.285 & 0.05 & Tidak Signifikan \\
3. & Self-Reflection & 0.272 & 0.05 & Tidak Signifikan \\
\hline
\end{tabular}

Keterangan:

Nilai Sig $(2$-tailed $)<\alpha(0,05)=$ signifikan

Nilai Sig $(2$-tailed $)>\alpha(0,05)=$ tidak signifikan

Tabel 3 menunjukkan bahwa tidak ada perbedaan skor self-regulation pada setiap aspek antara kelas eksperimen dan kelas kontrol pada pre-test atau sebelum pemberian layanan bimbingan kelompok dengan teknik self-instruction. Hal ini dapat diartikan bahwa perbandingan skor pre-test dapat dikatakan sesuai karena didasari oleh rata-rata skor yang setara. Setelah dilaksanakan layanan bimbingan kelompok dengan teknik self-instruction pada kelas eksperimen, kemudian dilakukan kembali uji independent sample t-tes pada post-test menunjukkan adanya perbedaan signifikan pada skor post-test aspek self-regulation. Hal ini dapat diartikan bahwa bimbingan kelompok dengan teknik self-instruction efektif untuk meningkatkan selfregulation siswa. Untuk lebih jelas dapat dilihat pada Tabel 4 berikut.

Tabel 4 Uji Independent Sample t-test Kelas Eksperimen dan Kelas Kontrol (Post-Test)

\begin{tabular}{ccccc}
\hline No. & Aspek & Asymp. Sig (2-tailed) & $\boldsymbol{\alpha}$ & Keterangan \\
\hline 1. & Forethought & 0.000 & 0.05 & Signifikan \\
2. & Performance/Volitional Control & 0.000 & 0.05 & \\
3. & self-Reflection & 0.000 & 0.05 & Signifikan \\
\hline
\end{tabular}

Keterangan:

Nilai Sig $(2$-tailed $)<\alpha(0,05)=$ signifikan

Nilai Sig $(2$-tailed $)>\alpha(0,05)=$ tidak signifikan

Secara umum tingkat self-regulation siswa sudah berada pada kategori sedang. Banyak individu yang secara tidak sadar telah berhasil meningkatkan self-regulation dalam dirinya melalui pengalaman terhadap tantangan yang ditemukan dalam kehidupan sehari-hari. Seperti konsep yang dikemukakan oleh Bandura tentang manusia yang bersifat optimistik, bahwa individu mampu mempelajari perilaku baru sepanjang kehidupannya (Feist \& Feist, 2006). Perilaku baru tersebut dapat dipelajari siswa dari pola asuh orang tua, interaksi dengan guru, dan interaksi dengan teman sebaya. Ketika siswa menyadari perilakunya kurang sesuai maka dirinya akan mencontoh perilaku lain yang lebih sesuai. Perilaku yang kurang sehat perlu dihentikan, karena kebanyakan individu memiliki kemampuan untuk merubah dirinya dengan meniru perilaku produktif individu lain dan menggunakan kemampuan kognitifnya untuk mencari penyelesaian masalah (Feist \& Feist, 2006).

Hasil penelitian ini sejalan dengan apa yang ditemukan oleh Matuga (2009) dalam penelitiannya menguji perubahan self-regulation dan orientasi tujuan siswa, serta menjelaskan hubungan antara kedua variabel tersebut dengan prestasi siswa. Hasil yang diperoleh adalah keseluruhan siswa memperoleh tingkat self-regulation pada kategori moderate (sedang). Secara keseluruhan dari hasil penelitian Matuga (2009) menunjukkan bahwa siswa dengan prestasi rata-rata dan siswa berprestasi menjadi kurang percaya diri dalam meregulasi dirinya terhadap proses belajarnya, sedangkan siswa yang kurang berprestasi menjadi lebih percaya diri akan kemampuannya dalam meregulasi diri terhadap proses belajarnya.

Self-regulation merupakan proses kepribadian yang penting, dimana individu berusaha untuk mengendalikan pikiran, perasaan, dorongan diri, dan performa dalam menyelesaikan tugas. Dikemukakan oleh Baumeister et al. (2006) self-regulation sangatlah adaptif, dan merupakan sifat manusia yang istimewa karena manusia mampu menolak dan mengubah respon, mengatur perilaku, dan mengganti dirinya agar sesuai dengan standar-standar sosial. Meskipun individu mampu memiliki self-regulation akan tetapi kapasitas tersebut kerap kali kurang dan belum ideal, oleh karena itu rendahnya self-regulation merupakan pusat dari sebagian besar masalah perilaku dan sosial yang mengganggu individu dalam masyarakat modern (Baumeister, Heatherton, \& Tice, 1994).

Satu pertanyaan muncul, apakah self-regulation dapat ditingkatkan? Berbagai pandangan teoritis memprediksikan bahwa peningkatan self-regulation sebagai hasil dari latihan. Individu akan memiliki keterampilan yang lebih baik apabila dilatih secara berulang-ulang, yang akan menghasilkan kebiasaan 


\section{KONSELING: Jurnal Ilmiah Bimbingan dan Konseling}

Vol.1, No.1, Oktober 2019

Available online: https://journal.ilininstitute.com/konseling

Bambang Setiawan, M. Solehuddin, Anne Hafina

baru, serta meningkatkan pengetahuan dan pemahaman. Bukti awal penelitian mengenai peningkatan selfregulation dilakukan oleh Muraven, Baumeister, \& Tice (1999) dengan hasil bahwa self-regulation dapat ditingkatkan dan diperkuat melalui latihan yang teratur. Hasil dari penelitian ini memberikan bukti awal bahwa partisipan yang mengikuti instruksi untuk melatih kontrol diri secara konsisten menunjukan peningkatan yang lebih baik pada self-regulation dan mampu meminimalisir penurunan self-regulation.

Para psikolog klinis dan konselor sering menghadapi klien/konseli yang bermasalah dengan masalah adiksi, perilaku destruktif, dan pola perilaku patologis, melalui peningkatan self-regulation akan memberikan bantuan yang kuat bagi para klien/konseli untuk mempercepat dan meningkatkan hasil konseling (Baumeister, 2006). Baumeister pun menambahkan bahwa para psikolog berusaha meningkatkan fungsi manusia, dan berusaha memperoleh berbagai hasil positif yang dihubungkan dengan self-regulation, mereka menemukan bahwa dengan peningkatan self-regulation dapat memberikan jalan yang berguna dan bernilai untuk memperoleh kesehatan, kebahagiaan, dan berbagai hasil positif lainnya.

Penelitian lainnya yang dilakukan oleh Oaten \& Cheng (2005) dengan merancang program belajar individu untuk siswa sebagai bentuk latihan untuk meningkatkan self-regulation. Dibandingkan dengan kelompok kontrol, siswa yang menyelesaikan program belajar dilaporkan memiliki tekanan emosional dan perasaan stres yang lebih rendah. Pikiran sebagai pusat untuk meningkatkan self-regulation memberikan kemudahan untuk meningkatkan self-regulation pada individu. Selain itu, melalui peningkatan self-regulation akan meningkatkan pula kendali dan kestabilan emosi. Pada penelitian Oaten \& Cheng, partisipan dapat meningkatkan self-regulation secara signifikan dari sebelum ke sesudah pemberian latihan. Oleh karena itu, peningkatan self-regulation dipandang sebagai inti dari kestabilan kepribadian individu.

Penelitian lainnya mengenai peningkatan self-regulation dilakukan oleh Gailliot et al. (2004), memberikan bukti bahwa interaksi dengan individu dari berbagai latar belakang ras dapat menyebabkan penurunan self-regulation yang merugikan individu, hal ini dikarenakan perbedaan perilaku, kebiasaan, dan cara berpikir yang kemungkinan dapat menimbulkan konfrontasi. Lebih lanjut, Gailliot et al. (2004) menggarisbawahi bahwa peningkatan self-regulation dapat membuat individu lebih kuat terhadap pengaruh negatif dari interaksi sosial.

Gailliot et al. (2004) juga melakukan penelitian mengenai peningkatan self-regulation dengan cara lain, partisipan diberikan tugas selama dua minggu. Tugas tersebut melibatkan proses verbal, yakni partisipan dilarang mengucapkan kata-kata kasar, berbicara dengan kalimat yang lengkap dan sopan, dan hanya menggunakan kata-kata baku. Untuk kelompok kontrol tidak diberikan latihan apapun. Penelitian ini menghasilkan bahwa dengan melatih self-regulation akan memberikan kendali diri dan terhindar dari penurunan ego.

Dari beberapa hasil penelitian tersebut, dapat disimpulkan bahwa dengan latihan yang terstruktur dan teratur, self-regulation dapat ditingkatkan secara optimal. Selain itu, individu yang mampu berlatih untuk meningkatkan self-regulation pada satu aspek atau indikator self-regulation, dirinya akan menjadi lebih mampu dalam meningkatkan aspek atau indikator self-regulation lainnya. Tujuan utama dari self-regulation ialah memungkinkannya individu untuk berperilaku sesuai dengan standar atau norma sosial yang berlaku. Dalam berbagai situasi, selalu ada satu standar mengenai perilaku yang tepat dan diinginkan secara sosial, akan tetapi kebanyakan individu memiliki kecenderungan dan terdorong untuk bertindak tidak sejalan dengan standar tersebut. Dalam situasi seperti itu, pengaruh dari self-regulation dapat menekan berbagai perilaku yang bertentangan dengan standar sosial.

Rendahnya self-regulation akan mengurangi upaya untuk mengatur perilaku yang diharapkan oleh standar pribadi dan sosial. Dengan kata lain, ketika individu gagal dalam meregulasi diri maka akan memiliki motivasi diri yang rendah dan berpengaruh besar terhadap perilakunya. Seperti dikemukakan oleh Baumeister et al. (2006) bahwa self-regulation diibaratkan sebagai kartu as dari kepribadian individu, hal ini karena akan memperkuat diri individu dan meningkatkan kemampuan dalam menghadapi tuntutan kehidupan serta sebagai pembimbing perilaku individu.

Terkait dengan tingkatan self-regulation siswa yang berada pada kategori sedang, tidak menjadikan upaya untuk meningkatkan self-regulation siswa berkurang urgensinya. Self-regulation memiliki pengaruh penting terhadap kehidupan individu. Salah satu yang terpenting adalah self-regulation berpengaruh terhadap pencapaian akademik siswa, hal ini dikarenakan self-regulation akan membantu siswa dalam menggunakan proses, strategi, dan respon spesifik untuk meningkatkan pencapaian akademiknya, serta menyadari potensinya dalam mencapai prestasi akademik (Zimmerman, 1989). Siswa yang memiliki selfregulation akan memiliki karakteristik, 1) secara personal dapat meningkatkan kemampuannya untuk belajar melalui penggunaan strategi metakognitif dan motivasional; 2) secara proaktif dapat menseleksi, menstruktur, dan merancang lingkungan belajar yang bermanfaat; dan 3) secara signifikan dapat memainkan peran dalam memilih bentuk dan sejumlah instruksi yang dibutuhkan.

Pelaksanaan pemberian layanan bimbingan kelompok dengan teknik self-instruction yang digunakan dalam penelitian ini memiliki tahapan-tahapan sebagai berikut. 
1) Tahap 1: Cognitive Modeling

Konselor mendemonstrasikan instruksi diri dengan suara yang keras. Perlu diperhatikan adalah instruksi diri berupa self-statement harus sesuai dengan materi layanan yang sedang diberikan. Contoh instruksi diri yang didemonstrasikan yaitu "Saya percaya setiap orang memiliki perannya masingmasing, oleh karena itu saya akan bertanggung jawab atas peran yang saya miliki, peran saya adalah siswa dan saya akan menjadi siswa yang bertanggung jawab".

2) Tahap 2: Overt External Guidance

Dibawah instruksi konselor, siswa melakukan verbalisasi diri seperti yang dilakukan konselor. Pada tahap ini, kata-kata yang diverbalisasikan oleh siswa harus sama dengan yang diinstruksikan konselor. Konselor melakukan instruksi secara langsung, mengarahkan, dan memperbaiki kesalahan siswa dalam mempraktekkan kata-kata dan/atau perilaku yang diinstruksikan.

3) Tahap 3: Overt Self-Guidance

Siswa melakukan verbalisasi diri dengan suara yang keras disertai menampilkan perilaku (performance) yang tepat. Pada tahapan ini, siswa melakukan verbalisasi diri secara berulang-ulang sampai menampilkan perilaku yang tepat sesuai dengan tujuan sesi tersebut.

4) Tahap 4: Faded Overt Self-Guidance

Siswa ditugaskan untuk melatih verbalisasi atau instruksi diri dengan suara yang perlahan dan diterapkan pula dalam kesehariannya.

5) Tahap 5: Covert Self-Instruction

Siswa melakukan verbalisasi atau instruksi diri secara tersembunyi seperti berbicara dalam hati. Siswa akan terbiasa melakukan verbalisasi atau instruksi diri dan mampu menampilkan perilaku yang tepat.

Penggunaan seting layanan bimbingan kelompok dalam penelitian ini sangat membantu dalam proses pemberian layanan. Bimbingan kelompok menjadikan proses pemberian layanan menjadi lebih efektif dan efisien. Interaksi yang terjadi dalam kelompok memberikan manfaat terhadap peningkatan selfregulation siswa. Hal ini terjadi karena siswa yang lebih paham terhadap materi layanan dapat membantu siswa lainnya yang masih belum paham terhadap materi layanan, sehingga peningkatan self-regulation siswa semakin mudah untuk dicapai.

Peningkatan self-regulation siswa kelas eksperimen tidak lepas dari bantuan bimbingan kelompok dengan teknik self-instruction yang terbukti efektif. Hasil penelitian ini sesuai dengan pandangan Boekaerts \& Corno (2005) bahwa teknik intervensi yang dapat digunakan untuk meningkatkan self-regulation adalah cognitive-behavior modification, yang bertujuan melatih dan mengganti kognisi dan perilaku maladaptif menjadi lebih adaptif. Teknik self-instruction sendiri merupakan teknik yang berasal dari teori cognitivebehavior modification yang dipelopori oleh Meichenbaum (1979). Hal senada dikemukakan oleh Bush (Ilfiandra, 2008) yang menyatakan bahwa "... cognitive-behavior therapy has become the preferred treatment for most emotional and behavior problems".

Self-regulation berkaitan dengan perubahan kognitif yang digunakan untuk menanamkan standar internal dalam diri siswa, sehingga diharapkan siswa dapat mengontrol perilaku sesuai dengan standar internalnya. Seperti dikemukakan oleh Meichenbaum (Dobson \& Dozois, 2011) bahwa perubahan kognitif dapat diubah dengan menggunakan verbalisasi diri. Diperkuat pula oleh Skinner (Hughes, 1985) bahwa verbalisasi diri dapat digunakan sebagai cara untuk mengontrol diri.

Vigotsky (Winsler, et al., 2009) mengungkapkan bahwa perubahan fundamental proses kognitif individu dimulai pada akhir tahun kedua kehidupan, atau ketika fase pre-intellectual language dan fase prelinguistic cognition menyatu untuk menciptakan pikiran secara verbal. Inti dari teori Vigotsky menyatakan bahwa verbalisasi internal dimulai dari pertukaran bahasa dengan orang lain dan selanjutnya diinternalisasikan sebagai pengarahan diri (self-directed). Individu dengan kemampuan verbalisasi internal akan mampu mengendalikan perilakunya sendiri dan mampu menginternalisasikan proses tersebut.

Salas et al. (2008) menemukan bahwa layanan kelompok berpengaruh positif terhadap hasil yang ingin dicapai dari setiap anggota kelompok, seperti perubahan kognitif, afektif, proses kerjasama, dan performa kelompok. Kemudian diperkuat oleh Ellington \& Dierdorff (2014) yang mengungkapkan bahwa secara khusus, performa kelompok dan kualitas kerja sama kelompok memberikan dampak positif terhadap peningkatan self-regulation siswa.

Keberhasilan bimbingan kelompok dengan teknik self-instruction untuk meningkatkan self-regulation siswa pada dasarnya tidak terlepas dari kelebihan yang dimiliki oleh teknik self-instruction dan bimbingan kelompok. Seperti dikemukakan oleh Sleight (Purnama, 2016) bahwa teknik self-instruction memiliki beberapa kelebihan sebagai berikut.

1) Efisien dalam waktu dan biaya. Hal ini dikarenakan konselor dapat menggunakan waktunya untuk melatih dan mengawasi konseli ketika melakukan self-instruction, namun tetap memiliki waktu untuk melakukan proyek layanan yang lain.

2) Teknik self-instruction dapat mencakup rentang yang luas dalam permasalahan konseli. 


\section{KONSELING: Jurnal Ilmiah Bimbingan dan Konseling}

Vol.1, No.1, Oktober 2019

Available online: https://journal.ilininstitute.com/konseling

Bambang Setiawan, M. Solehuddin, Anne Hafina

3) Teknik self-instruction memungkinkan konseli untuk memegang kendali dalam hal pemberian instruksi. Jenis kendali dapat beragam, mulai dari kendali sederhana terhadap langkah-langkah instruksi, kendali untuk menentukan tujuan terapi atau konseling, dan kendali untuk menentukan materi instruksi yang konseli butuhkan.

\section{Simpulan dan Saran}

Bimbingan kelompok dengan teknik self-instruction secara keseluruhan terbukti efektif untuk meningkatkan self-regulation siswa. Berdasarkan hasil tersebut kelas eksperimen mengalami peningkatan tingkat self-regulation yang signifikan. Pada pre-test kelas eksperimen memperoleh skor 62,07 dan tingkat selfregulation berada pada kategori sedang, kemudian setelah diberikan intervensi bimbingan kelompok dengan teknik self-instruction atau post-test kelas eksperimen memperoleh skor 70,74 dan tingkat selfregulation berada pada kategori tinggi. Berdasarkan hasil tersebut telihat bahwa terjadi peningkatan skor sebesar 8,67 dan juga terjadi perubahan kategori self-regulation kelas eksperimen dari sedang menjadi tinggi. Hal ini dapat diasumsikan bahwa layanan bimbingan kelompok dengan teknik self-instruction secara empiris terbukti efektif untuk meningkatkan self-regulation.

Konselor perlu menyadari bahwa peningkatan self-regulation harus diberikan kepada seluruh siswa, hal ini akan berguna bagi siswa dalam menjalani seluruh proses belajar di sekolah. Maka dari itu, peningkatan self-regulation harus menjadi salah satu prioritas layanan yang diberikan kepada siswa. Selfregulation merupakan subjek penelitian yang sangat menarik, hal ini karena urgensi dari self-regulation yang dapat menyentuh seluruh aspek kepribadian manusia. Peneliti mengharapkan, akan bermunculan penelitian-penelitian baru yang mengkaji tentang self-regulation secara lebih mendalam dan komprehensif. Semoga hasil penelitian ini dapat menjadi pendorong bagi penelitian tentang self-regulation di Indonesia.

\section{Ucapan Terimakasih}

Penulis memberikan apresiasi dan terima kasih kepada Dr. M. Solehuddin, MA., M.Pd dan Dr. Anne Hafina, M.Pd yang telah memberikan bimbingan, dukungan, dan motivasi selama proses penulisan penelitian ini, serta atas kritik dan rekomendasi yang diberikan telah membantu terselesaikannya penelitian ini. Penulis juga memberikan apresiasi dan terima kasih kepada semua pihak yang telah membantu, khususnya kepada Kepala Sekolah SMK Negeri 1 Talaga Drs. H. Aan Hartawan, M.H.

\section{Daftar Rujukan}

Bandura, A. (1991). Social Cognitive Theory of Self-Regulation. Organizational Behavior and Human Decision Processes, 50 (1), hlm. 248-287. DOI: 10.1016/0749-5978(91)90022-L

Baumeister, R. F., Heatherton, T. F. \& Tice, D. M. (1994). Losing Control: How and Why People Fail at SelfRegulation. San Diego, CA: Academic Press.

Baumeister, R. F. et al. (2006). Self-Regulation and Personality: How Interventions Increase Regulatory Success, and How Depletion Moderates the Effect of Traits on Behavior. Journal of Personality, 74 (6), hlm. 1773-1802. DOI: $10.1111 / j .1467-6494.2006 .00428 . x$

Blair, C. et al. (2010). Self-regulation as the Interface of Emotional and Cognitive Development: Implications for Educational and Academic Achievement. Dalam Hoyle, Rick H. Handbook of Personality and Self-regulation. United Kingdom: Wiley-Blackwell Publishing Ltd.

Boekaerts. M. \& Corno, L. (2005). Self-Regulation in the Classroom: A Perspective on Assessment and Intervention. Applied Psychology: An International Review, 54 (2), hlm. 199-231. DOI: 10.1111/j.14640597.2005.00205.X

Bryant, L. E. \& Budd, K. S. (1982). Self-Instructional Training to Increase Independent Work Performance in Prechoolers. Journal of Applied Behavior Analysis, 15 (2). hlm. 259-271. DOI: $10.1901 /$ jaba.1982.15-259

Bughental, D. B. et al. (1978). Attributional and Behavioral Changes Following Two Behavior Management Intervention with Hyperactive Boys: A Follow-Up Study. Child Developmnet, 49, hlm. 247-250.

Bukhtawer, N. et al. (2014). Personality Traits and Self-Regulation: A Comparative Study among Current, Relapse and Remitted Drug Abuse Patients. Health Journal, 6, (1), hlm. 1368-1375. DOI: $10.4236 /$ health.2014.612168

Burgio, L. D. et al. (1980). A Self-Instructional Package for Increasing Attending Behavior in Educable Mentally Retarded Children. Journal of Applied Behavior Analysis, 13 (3), hlm. 443-459. DOI: $10.1901 /$ jaba.1980.13-443

Campbell, D. T. \& Stanley, J. C. (1963). Experimental and Quasi-Experimental Designs for Research. Boston: Houghton Mifflin Company. 
Carver, C. S. \& Scheier, M. F. (2000). On the Strcuture of Behavioral Self-Regulation. Dalam Boekaerts, Monique et al. Handbook of Self-Regulation. San Diego: Academic Press.

Chong, W. H. (2007). The Role of Personal Agency Beliefs in Academic Self-Regulation: An Asian Perspective. School Psychology International, 28 (1), hlm. 63-76. DOI: 10.1177/0143034307075681

de Bruin, A. B. et al. (2001). Generating Keywords Improves Metacomprehension and Self-Regulation in Elementary and Middle School Children. Journal of Experimental Child Psychology, 109 (3), hlm. 294310. DOI: $10.1016 /$ j.jecp.2011.02.005

Dobson, K. S. \& Dozois, D. J. A. (2001). Historical and Philosophical Bases of the Cognitive-Behavioral Therapies. Dalam Dobson, Keith S. Handbook of Cognitive-Behavioral Therapies. New York: The Guildford Press.

Eisenberg, N. et al. (2005). Associations of Emotion-related regulation with Language Skills, Emotion Knowledge, and Academic Outcomes. New Direction in Child and Adolescent Development, 109 (1), hlm. 109-118. DOI: $10.1002 / \mathrm{cd} .143$

Ellington, J. K. \& Dierdorff, E. C. (2014). Individual Learning in Team Training: Self-Regulaion and Team Context Effects. Small Group Research, 45 (1), hlm. 37-67. DOI: 10.1177/1046496413511670

Feist, J. \& Feist, G. J. (2006). Theories of Personality. New York: McGraw Hill.

Furqon dan Emilia. (2010). Penelitian Kualitatif dan Kuantitatif (Beberapa Isu Kritis). Bandung: SPs UPI.

Gailliot, M. et al. (2004). Increasing Self-Regulatory Strength Can Reduce the Depleting Effect of Suppressing Stereotypes. Manuscript Submitted for Publication.

Hall, C. S. \& Lindzey, G. (1985). Introduction to Theories of Personality. Singapore: John Wiley \& Sons.

Harris, K. R. et al. (2005). Self-Monitoring of Attention Versus Self-Monitoring of Academic Performance: Effects among Students with ADHD in the General Education Classroom. Journal of Special Education, 39 (3), hlm. 145-156. DOI: 10.1177/00224669050390030201

Higgins, E. T. (1996). The Self Digest: Self-Knowledge Serving Self-Regulatory Functions. Journal of Personality and Social Psychology, 71 (1), hlm. 1062-1083. DOI: 10.1037/0022-3514.71.6.1062

Hughes, C. (1985). The Effect of Self-Instruction on On-Task Behavior and Work Performance in Vocational Training Setting. (Tesis). Faculty of the School of Education, Eastern Montana College, USA.

Husna, A. N. et al. (2014). Regulasi Diri Mahasiswa Berprestasi. Jurnal Psikologi Universitas Diponegoro, 13 (1), hlm. 50-63. DOI: 10.14710/jpu.13.1.50-63

Ilfiandra. (2008). Model Konseling Kelompok Berbasis Pendekatan Kognitif Perilaku Untuk Mengurangi Gejala Prokrastinasi Akademik (Disertasi). Bandung: Sekolah Pascasarjana, Universitas Pendidikan Indonesia, (Tidak Diterbitkan).

Jarvela, S. \& Jarvenoja, H. (2011). Socially Constructed Self-Regulated Learning and Motivation Regulation in Collaborative Learning Groups. Teachers College Record, 113 (2), hlm. 350-374. DOI: $10.4236 /$ psych. 2016.713153

Matuga, J. M. (2009). Self-Reglation, Goal Orientation, and Academic Achievement of Secondary Studies in Online University Courses. Journal Technology \& Society, 12 (3), hlm. 4-11.

Meichenbaum, D. (1979). Cognitive-Behavior Modification: An Integrative Approach (second printing). New York: Plenum Press.

Mischel, W. (1996). From Good Intention to Willpower. Dalam Gollwitzer, P \& Bargh, J. The Psychology of Action. New York: Guilford.

Muraven, M., Baumeister, R. F., \& Tice, D. M. (1999). Longitudinal Improvement of Self-Regulation Through Practice: Building Self-Control Through Repeated Exercise. Journal of Social Psychology, 139, hlm. 446-457. DOI: 10.1080/00224549909598404

Oaten, M. \& Cheng, K. (2005). Academic Examination Stress Impairs Self-Control. Journal of Social and Clinical Psychology, 24, hlm. 254-279. DOI: 10.1521/jscp.24.2.254.62276

Purnama, A. A. (2016). Efektivitas Self-Instruction Training untuk Meningkatkan Resiliensi Siswa. (Tesis). Bandung: Departemen Psikologi Pendidikan, Sekolah Pascasarjana, Universitas Pendidikan Indonesia, (Tidak Diterbitkan).

Ross, T. \& Fontao, M. I. (2007). The Relationship of Self-Regulation and Aggression: An Empirical Test of Personality Systems Interaction Theory. International Journal of Offender Therapy and Comparative Criminology, 52 (5), hlm. 554-570. DOI: 10.1177/0306624X07308667

Rusmana, N. (2009). Bimbingan dan Konseling Kelompok di Sekolah (Metode, Teknik dan Aplikasi. Bandung: Rizqi Press.

Salas, E. et al. (2008). Does Team Training Improve Team Performance? A Meta-Analysis. Human Factors, 50 (1), hlm. 903-933. DOI: 10.1518/001872008X375009

Trope, Y. \& Liberman, N. (2000). Temporal Construal and Time-Dependent Changes in Preference. Journal of Personality and Social Psychology, 79 (1), hlm. 876-889. DOI: 10.1037/0022-3514.79.6.876 


\section{KONSELING: Jurnal Ilmiah Bimbingan dan Konseling}

Vol.1, No.1, Oktober 2019

Available online: https://journal.ilininstitute.com/konseling

Bambang Setiawan, M. Solehuddin, Anne Hafina

Winsler, A., Fernyhough, C., \& Montero, I. (2009). Private Speech, Executive Functioning, and the Development of Verbal Self-Regulation. Cambridge, UK: Cambridge University Press.

Wolters, C. A. (2011). Regulation of Motivation: Contextual and Social Aspects. Teachers College Record, 113 (2), hlm. 265-283.

Zimmerman, B. J. (1989). Models of Self-Regulated Learning and Academic Achievement. Dalam Zimmerman, B. J. \& Schunk, D. H. Self-Regulated Learning and Academic Achievement: Theory, Research, and Practice. New York: Springer-Verlag.

Zimmerman, B. J. (2000). Attaining Self-Regulation: A Social Cognitive Perspective. Dalam Boekaerts, M. et al. Handbook of Self-Regulation. San Diego: Academic Press.

Zimmerman, B. J. (2008). Investigating Self-Regulation and Motivation: Historical Background, Methodological Developments, and Future Prospects. American Educational Research Journal, 45 (1), hlm. 166-183. DOI: 10.3102/0002831207312909

Zimmerman, B. J. \& Schunk, D. H. (2008). Motivation: An Essential Dimension of Self-Regulated Learning. Dalam Schunk, D. H. \& Zimmerman, B. J. Motivation and Self-Regulated Learning: Theory, Research, and Applications. New Jersey: Lawrence Erlbaum Associates. 